University of Missouri-Kansas City School of Law

UMKC School of Law Institutional Repository

\title{
Government Involvement in Pharmaceutical Development Can Come Back to Haunt a Drug Company
}

Christopher M. Holman

University of Missouri - Kansas City, School of Law

Follow this and additional works at: https://irlaw.umkc.edu/faculty_works

\section{Recommended Citation}

Christopher M. Holman, Government Involvement in Pharmaceutical Development Can Come Back to Haunt a Drug Company, 40 Biotechnology Law Report 4 (2021).

Available at: https://irlaw.umkc.edu/faculty_works/223

This Article is brought to you for free and open access by the Faculty Scholarship at UMKC School of Law Institutional Repository. It has been accepted for inclusion in Faculty Works by an authorized administrator of UMKC School of Law Institutional Repository. For more information, please contact shatfield@umkc.edu. 
PRE-PRINT VERSION (For print version see Christopher M. Holman, Government Involvement in Pharmaceutical Development Can Come Back to Haunt a Drug Company, 40

BIOTECHNOLOGY LAW REPORT 4 (2021).)

\title{
Government Involvement in Pharmaceutical Development Can Come Back to Haunt a Drug Company
}

\author{
Christopher M. Holman*
}

\begin{abstract}
The U.S. government has long played a significant role in pharmaceutical innovation, often through the funding of research, or collaboration in clinical trials. Unfortunately, government involvement can come at a cost for innovative drug companies, leading to allegations that taxpayers are being required to "pay twice" for the resulting drugs, particularly when the drug is considered essential and is offered at a price that is seen as "unreasonably" high. This Article discusses two aspects of ongoing efforts to leverage government involvement in pharmaceutical development and commercialization as a means for regulating of drug prices. The first is the assertion that the government can invoke various provisions of the Bayh-Dole Act, including, but not limited to march-in rights, to compel companies that have built upon federally-funded research to lower the price it charges for the resulting drug and/or license competing companies to commercialize generic versions of the drug. The other is an attempt by the federal government to use its own patents, which arose out research conducted in collaboration with a private company, as leverage to force that company to lower the price of its drug and/or to fund programs intended to expand access to the drug.
\end{abstract}

The U.S. government is not in the business of developing and commercializing innovative new drugs on its own -- it generally leaves that high-cost, high-risk, and potentially highly profitable endeavor to private companies. ${ }^{1}$ Nevertheless, the government has long played a significant role in pharmaceutical innovation, often through the funding of research that occurs at universities

\footnotetext{
* Christopher M. Holman, Professor of Law, University of Missouri-Kansas City School of Law; Senior Fellow, Center for the Protection of Intellectual Property, Antonin Scalia Law School, George Mason University; and Executive Editor, Biotechnology Law Report.

${ }^{1}$ Birch Bayh and Robert Dole, "Our Law Helps Patients Get New Drugs Sooner," Washington Post 11 Apr. 2002: A28. ("Government alone has never developed the new advances in medicines and technology that become commercial products. For that, our country relies on the private sector.")
} 
and non-profit institutions that results in discoveries and patents that the public sector then licenses and translates into FDA-approved medicines. Sometimes drug companies collaborate with federal agencies in clinical trials that can speed the approval of the drug, or validate or expand indications. This government involvement with drug development efforts occurring in the private sector can be highly beneficial for all concerned, facilitating pharmaceutical innovation and commercialization that can provide tremendous benefits to human patients.

Unfortunately, government involvement can come at a cost for innovative drug companies, leading to allegations that taxpayers are being required to "pay twice" for the resulting drugs, particularly when the drug is considered essential and is offered at a price that is seen as "unreasonably" high. This Article discusses two aspects of ongoing efforts to leverage government involvement in pharmaceutical development and commercialization as a means for regulating of drug prices.

The first is the assertion that the government can invoke various provisions of the Bayh-Dole Act, including, but not limited to march-in rights, to compel companies that have built upon federally-funded research to lower the price it charges for the resulting drug and/or license competing companies to commercialize generic versions of the drug. The other is an attempt by the federal government to use its own patents, which arose out research conducted in collaboration with a private company, as leverage to force that company to lower the price of its drug and/or to fund programs intended to expand access to the drug. The Bayh-Dole issue has been around for quite a while, and has been attempted on a number of occasions, unsuccessfully so far, but there is reason to think that its proponents might find a more receptive administration with the election of Joe Biden. The federal government's assertion of its own patents against a private sector collaborator is a more novel development that certainly bears watching.

\section{Leveraging Bayh-Dole to regulate drug prices}

\section{The "taxpayer pays twice argument"}

There have long been those who argue that the U.S. taxpayer is "paying twice" for drugs that were brought to market with some assistance from federal funding. Examples would include federal grant money used in research that discovered the active ingredient, or funding of clinical trials that played a role in the approval of the drug, or the validation of the drug for the use in some particular indication. The argument has long held an appeal for those who see it as a potential path to lower drug prices, including some members of the U.S. Congress.

For example, in 1994 the House Small Business Subcommittee held a Federal Funding of Medical Research hearing to investigate allegations that the Scripps Research Institute had failed to disclose that many of its patents arose out of federally funded research, as required by the Bayh-Dole Act. ${ }^{2}$ Representative Ron Wyden (D-Oregon) began the hearing by noting that federal agencies such as the National Institutes of Health (NIH) and National Science Foundation

\footnotetext{
${ }^{2}$ C-SPAN, Federal Funding of Medical Research (July 11, 1994), available at https://www.c-span.org/video/?585911/federal-funding-medical-research (last visited December 10, 2020).
} 
(NSF) fund research and medical breakthroughs occurring at college universities and other medical research institutions, and opining that:

as a result of this enormous federal investment, the federal government has certain rights and interests, including an assurance of reasonable pricing and availability of products commercialized as a result of this research. ... The government can use its leverage to force co-licensing of technologies and competing drugs or devices. In the case of flagrant disregard of the public interest, the government can even take ownership of a patent. ${ }^{3}$

One of those testifying before the subcommittee was Michael Davis, a law professor at the University of Cleveland School of Law and outspoken proponent of the "taxpayer pays twice" narrative. ${ }^{4}$ Davis Professor began his testimony with an anecdote:

Listening to the panel today I was reminded of a story I saw in the paper the other day about some fellow that had his car stolen. It was one of those carjackings where they took the owner as well as the car. [After] 100 miles they threw him out or something. Police came and questioned him and he said it wasn't so bad they stole the car, but they made him pay for the gas and tolls, and I think that's what's happening to the taxpayer in this situation. Underreporting of inventions developed with government support means the government cannot track the compliance of contractors who are required to market government supported inventions at reasonable prices under [the Bayh-Dole Act]. To the extent the government can better track these inventions contractors will be encouraged to comply with Bayh-Dole, because, among other things, the failure to comply with Bayh-Dole can trigger march-in rights by the government, allowing the licensing of such inventions to other firms. ${ }^{5}$

In his testimony, Professor Davis opined that research institutions whose patents arose out of federal funding, and are thus subject to certain provisions of the Bayh-Dole Act, "will more readily respond to the public interest" in the form of lower drug prices. He also suggested that, even in the case of patents that did not arise out of federally funded research (the example he gave was the use of AZT to treat AIDS, a hot topic at the time), the federal government can seize patents under "eminent domain theories" that would force the patent owner to lower the price of its drug, opining that "the seizure of a patent under eminent domain theories is similar, though more draconian I suppose, than the march-in rights afforded by Bayh-Dole, but in many ways the economic dynamics are similar."

Although Professor Davis suggested that the government could seize any patent under eminent domain theories, the primary focus of his testimony was on the potential use of Bayh-Dole to compel licensing of pharmaceutical patents arising out of federally funded R\&D. Over the years Bayh-Dole has been a perennial favorite of the "taxpayers pay twice" crowd, who have long

\footnotetext{
${ }^{3} I d$.

4 Professor Davis recently passed away. Cleveland State University, Remembering Professor Emeritus Mickey Davis, November 16, 2020, available at https://www.law.csuohio.edu/newsevents/news/remembering-professoremeritus-mickey-davis (last visited December 10, 2020).

${ }^{5}$ Federal Funding of Medical Research, supra note 1.
} 
asserted that two provisions of the Act provide a statutory basis for the appropriation of federally funded patented technology: (1) the nonexclusive license to the patent which the government retains for its own use, and (2) the government's march-in rights. Of the two, march-in rights are probably more pertinent, and have been the main focus of these efforts, but the nonexclusive license provision has also been raised in this context. And just this year, a leading proponent of the "taxpayers pay twice" movement, Knowledge Ecology International (KEI), sent a letter to federal agencies outlining theories whereby other provisions of Bayh-Dole could be used to pressure a drug company to lower the price it charges for its drug and/or to compel licensing of the company's patents, including patents that arose independently of any federal funding, as described in more detail below. ${ }^{6}$

\section{Origins of the Bayh-Dole Act}

Congress enacted the Bayh-Dole Act in 1980, and it is currently codified as $\S \S 200-212$ of the Patent Act. ${ }^{7}$ Bayh-Dole addresses the rules governing the licensing of governmentowned inventions, including the rights of federal "contractors" to elect title to inventions made with federal funding. ${ }^{8}$

In 2004, Senator Birch Bayh, one of the primary sponsors of the Act, recounted the history behind the passage of Bayh-Dole, and the economic environment that existed prior to its enactment. ${ }^{9}$ He explained that in the 1970s "America had lost its technological advantage," including its competitive position in a number of key industries such as steel and auto production. The number of patents issued each year, and in particular the number of patentable inventions made under federally supported research, had been in decline for years. Investment in research and development in the 1970s was static.

Sen. Bayh surmised that America's decline in innovation had arisen in large part due to a failure to commercialize technologies protected by U.S. government patents. An investigation at the U.S. Patent and Trademark Office (PTO), for example, had disclosed that the U.S. government owned 28,000 patents, but only $4 \%$ of those have been developed as a product for use by the consumer. He explained:

Close examination disclosed that most patents procured as a result of government research grants, particularly those developed in university laboratories, resulted from basic research. The ideas patented were in the embryonic stages of

\footnotetext{
${ }^{6}$ James Love, Three areas in Section 202 of the Bayh-Dole Act that require action to ensure sufficient rights in patents on coronavirus relevant inventions (March 14, 2020), available at https://www.keionline.org/32364.

735 U.S.C. § 200-212. Also referred to as the Patent and Trademark Law Amendments Act (Pub. L. 96-517, December 12, 1980).

835 U.S.C. § 201(c) defines a "contractor" as any person, small business firm, or nonprofit organization that is a party to a federal funding agreement. Executive Order 12591, issued by President Reagan three years later, expanded this definition to include large businesses. Memorandum on Government Patent Policy from President Ronald Reagan, to Heads of Executive Departments and Agencies, February 18, 1983, http://www.presidency.ucsb.edu/ws/index.php?pid=40945\&st=\&st1=.

${ }^{9} \mathrm{NIH}$ Public Meeting on Norvir/Ritonavir March-in Request (May 25, 2004), available at https://www.ott.nih.gov/sites/default/files/documents/2004NorvirMtg/2004NorvirMtg.pdf.
} 
development. Often millions of dollars were required to produce a sophisticated product necessary for marketability. Since the government refused to permit ownership of the patents, private industry and business refused to invest the resources necessary to bring the products to consumers. As Thomas Edison said: "Invention is $1 \%$ inspiration and $99 \%$ perspiration." With regard to publicly funded research, government typically funds the inspiration and industry the perspiration. ${ }^{10}$

At the time, some members of Congress opposed the legislation, arguing that "if the taxpayer funds the research, the taxpayer should own the ideas produced." And prior to Bayh-Dole, the patenting and licensing policies of many federal agencies largely reflected that view. Unfortunately, as explained by Sen. Bayh, "the result of this policy was billions of taxpayer dollars spent on thousands of ideas and patents which were collecting dust in the PTO. The taxpayers were getting no benefit whatsoever."11

As explained by Professor Jay Thomas in a 2016 Congressional Research Service (CRS) Report:

[In enacting Bayh-Dole, Congress] accepted the proposition that the lack of patent title discouraged private enterprise from advancing early-stage technologies into the marketplace. For example, suppose that a university researcher identifies a promising chemical compound using funds provided by the National Institutes of Health (NIH). Some observers believed that under pre-Bayh-Dole Act practices, a brand-name pharmaceutical company would be unlikely to undertake costly and risky clinical trials in order to convert that early-stage research into a drug approved by the Food and Drug Administration. Absent patent protection, generic firms could quickly introduce competing products. This view accepts that patents provide incentives not just for individuals to invent, but also to commercialize completed inventions. ${ }^{12}$

Under Bayh-Dole, a "contractor" (often a university or non-profit research institution that has received research grant funding) is permitted to retain title to any "subject invention," which the Act defines as "any invention of the funding recipient conceived or first actually reduced to practice in the performance of work under a funding agreement." 13 The institution must commit to commercialization of the invention within a predetermined, agreed upon, timeframe. The government may, however, retain title under "exceptional circumstances when it is determined by the agency that restriction or elimination of the right to retain title to any subject invention will better promote the policy and objectives of this chapter." Additionally, the government may withhold title if the contractor "is not located in the United States or does not have a place of business located in the United States or is subject to the control of a foreign government"; in

$10 / d$.

${ }^{11} / d$.

12 John R. Thomas, March-in Rights Under the Bayh-Dole Act, Congressional Research Service Report R44597 (2016) (citing F. Scott Kieff, "Property Rights and Property Rules for Commercializing Inventions," Minnesota Law Review, vol. 85 (2001), p. 697).

1335 U.S.C. $\S 201(e)$. 
situations associated with national security; or when the work is related to the naval nuclear propulsion or weapons programs of the Department of Energy. ${ }^{14}$

The policy and objectives of Bayh-Dole are set forth explicitly in 35 U.S.C. 200:

It is the policy and objective of the Congress to use the patent system to promote the utilization of inventions arising from federally supported research or development; to encourage maximum participation of small business firms in federally supported research and development efforts; to promote collaboration between commercial concerns and nonprofit organizations, including universities; to ensure that inventions made by nonprofit organizations and small business firms are used in a manner to promote free competition and enterprise; to promote the commercialization and public availability of inventions made in the United States by United States industry and labor; to ensure that the Government obtains sufficient rights in federally supported inventions to meet the needs of the Government and protect the public against nonuse or unreasonable use of inventions; and to minimize the costs of administering policies in this area. ${ }^{15}$

Note there is nothing in Section 200 to suggest that Bayh-Dole was intended to regulate the price of products resulting from the commercialization of inventions arising out of federally funded research.

A 2002 opinion piece in The Economist had this to say about Bayh-Dole:

Possibly the most inspired piece of legislation to be enacted in America over the past half-century was the Bayh-Dole Act of 1980. Together with amendments in 1984 and augmentation in 1986, this unlocked all the inventions and discoveries that had been made in laboratories throughout the United States with the help of taxpayers' money. More than anything, this single policy measure helped to reverse America's precipitous slide into industrial irrelevance. ${ }^{16}$

The NIH's "reasonable pricing" clause experience

In the years following passage of Bayh-Dole, members of Congress continued to express concerns that taxpayers were not receiving an appropriate monetary return on their investment in biomedical research. In response to these concerns, in 1989 the NIH adopted a policy stating that there should be "a reasonable relationship between the pricing of a licensed product, the public investment in that product, and the health and safety needs of the public." ${ }^{17}$ It was applied in Cooperative Research and Development Agreement (CRADA) negotiations between NIH intramural laboratories and potential private collaborative partners interested in engaging in collaborative research. This "reasonable pricing" clause was required in exclusive licenses to inventions made under NIH CRADAs.

\footnotetext{
1435 U.S.C. § $202(a)$.

1535 USC § 200.

16 "Innovations Golden Goose." The Economist 14 Dec. 2002: 3, available at

https://www.economist.com/technology-quarterly/2002/12/14/innovations-golden-goose

17 DHHS/NIH Report to Congress, A Plan to Ensure Taxpayers' Interests are Protected (July, 2001) 10, available at https://www.ott.nih.gov/sites/default/files/documents/policy/wydenrpt.pdf
} 
But industry balked at this imposition of a "reasonable pricing" requirement, seeing it as a form of price control. Many companies withdrew from any further interaction with NIH rather than agree to the stipulation. Both NIH and its industry counterparts came to the realization that this policy had the effect of posing a barrier to expanded research relationships and, therefore, was contrary to the purpose and policy behind Bayh-Dole.

The NIH convened panels that included government scientists and administrators, industry, academia, and patient advocacy groups to review the "reasonable pricing" policy. Ultimately, the panels concluded that the policy did not serve the best interests of technology development and recommended that NIH rescind the requirement. NIH accepted the recommendation and revoked the policy in $1995 .^{18}$

The negative impact of NIH's "reasonable pricing clause" policy on collaborative research are evidenced in the relatively flat growth rate of CRADAs that occurred between 1990 and 1994, and the subsequent rebound in CRADAs following revocation of the policy. ${ }^{19}$

\section{Government's retained rights under Bayh-Dole}

Under Bayh-Dole the government retains certain rights in subject inventions, including the nonexclusive license mentioned above and march-in rights. More particularly regarding the frormer, the government retains "a nonexclusive, nontransferable, irrevocable, paid-up license to practice or have practiced for or on behalf of the United States any subject invention throughout the world." 20 Professor Thomas observed in his CRS Report that "this license solely benefits the federal government," seeming to suggest that it could not be asserted on behalf of any other entity, "such as a generic drug company or other enterprise." 21 In 1999 an NIH Working Group on Research Tools concluded that while "[t]his license gives the NIH, and any other agency of the Federal government, the right to use any patented research tool arising in the course of federally-sponsored research without liability for patent infringement[, it] is not clear whether NIH's retained license [] allows NIH to authorize use of subject inventions by other recipients of NIH grants. Some agencies take the position that the activities of grantees are covered by the exemption, but NIH has considered it an open question."22

The government also retains "march-in rights," which allows a federal agency to require a contractor to license a third party to use the invention under certain prescribed circumstances. ${ }^{23}$ The march-in provisions are set out in Section 203(a), which states that:

With respect to any subject invention in which a small business firm or nonprofit organization has acquired title under this chapter, the Federal agency under whose funding agreement the subject invention was made shall have the right, in accordance with such procedures as are provided in regulations promulgated

\footnotetext{
$18 / d$.

19 Id. at 11.

2035 U.S.C. $\S 202(c)(4)$.

${ }^{21}$ John R. Thomas, March-in Rights Under the Bayh-Dole Act, Congressional Research Service Report R44597 6 (2016).

${ }^{22}$ Report of the National Institutes of Health (NIH) Working Group on Research Tools, Appendix D (1999), available at http://www.nih.gov/news/researchtools/appendd.htm.

${ }^{23} 35$ U.S.C. § 203.
} 


\section{PRE-PRINT VERSION}

hereunder, to require the contractor, an assignee, or exclusive licensee of a subject invention to grant a nonexclusive, partially exclusive, or exclusive license in any field of use to a responsible applicant or applicants, upon terms that are reasonable under the circumstances, and if the contractor, assignee, or exclusive licensee refuses such request, to grant such a license itself, if the Federal agency determines that such -

(1) action is necessary because the contractor or assignee has not taken, or is not expected to take within a reasonable time, effective steps to achieve practical application of the subject invention in such field of use;

(2) action is necessary to alleviate health or safety needs which are not reasonably satisfied by the contractor, assignee, or their licensees;

(3) action is necessary to meet requirements for public use specified by Federal regulations and such requirements are not reasonably satisfied by the contractor, assignee, or licensees; or

(4) action is necessary because the agreement required by section 204 has not been obtained or waived or because a licensee of the exclusive right to use or sell any subject invention in the United States is in breach of its agreement obtained pursuant to section $204 .^{24}$

Over the years, several march-in petitions have been filed with the intent of bringing down the price of a drug, and these petitions have focused on the first two of the four conditions set forth in $\S 203(\mathrm{a})$, alleging that the patentee (typically a drug company that has licensed the patent from a federal grantee, such as a university) has failed (1) "to achieve practical application of the subject invention" and/or has not (2) "reasonably satisfied... health or safety needs." Significantly, Bayh-Dole defines the term "practical application" as:

To manufacture in the case of a composition or product, to practice in the case of a process or method, or to operate in the case of a machine or system; and, in each case, under such conditions as to establish that the invention is being utilized and that its benefits are to the extent permitted by law or Government regulations available to the public on reasonable terms." 25

Proponents of the "taxpayer pays twice" theory read Bayh-Dole as authorizing government march-in when the "benefits" of a subject invention have not been made "available to the public on reasonable terms," which they equate with a requirement that a patented drug be offered to U.S. consumers at a "reasonable price."

\section{The Arno and Davis Article}

The theory that Congress intended Bayh-Dole to be used as a means for regulating drug prices, by allowing the government to march-in and impose compulsory licensing in cases in which a drug is not priced "reasonably," was formally developed in an influential (but factually

\footnotetext{
${ }^{24} / d$.

${ }^{25} 35$ U.S.C. § $201(\mathrm{f})($ emphasis added).
} 
questionable) law review article published by Professors Arno and Davis in $2001 .{ }^{26}$ They went on to popularize their theory in a 2002 opinion piece published in the Washington Post, which lays out the "paying twice for the same drugs" theory and argues that the solution is for the government to use its powers under Bayh-Dole to make drugs more affordable. ${ }^{27}$ The op-ed characterizes Bayh-Dole as:

a provision of U.S. patent law that states that practically any new drug invented wholly or in part with federal funds will be made available to the public at a reasonable price. If it is not, then the government can insist that the drug be licensed to more reasonable manufacturers, and, if refused, license it to third parties that will make the drug available at a reasonable cost. The idea behind Bayh-Dole is to protect taxpayers' investment in drug research and development.

It goes on to argue that Bayh-Dole "holds the potential to make pharmaceuticals significantly more affordable for all Americans.... Unfortunately, no one is enforcing it." The op-ed states that the U.S. taxpayer is "the single largest investor in the pharmaceutical industry," and asks "why aren't we seeing lower drug prices?," given that "we've already paid for the cost of research." Arno and Davis went on to chastise the federal government for being "an irresponsible investor of public funds," because it has never enforced Bayh-Dole. They attributed this to federal agencies such as NIH not understanding the law, or being reluctant to exercise their responsibilities.

\section{Bayh and Dole respond}

Senators Bayh and Dole have vehemently refuted the contention that Bayh-Dole's marchin provisions were intended as a mechanism for the government to regulate drug prices. In response to Arno and Davis' op-ed, they jointly sent a letter to the Washington Post explaining that:

Bayh-Dole did not intend that government set prices on resulting products. The law makes no reference to a reasonable price that should be dictated by the government. This omission was intentional; the primary purpose of the act was to entice the private sector to seek public-private research collaboration rather than focusing on its own proprietary research.

The [Arno and Davis article] mischaracterized the rights retained by the government under Bayh-Dole. The ability of the government to revoke a license granted under the act is not contingent on the pricing of a resulting product or tied to the profitability of a company that has commercialized a product that results in part from government-funded research. The law instructs the government to revoke

\footnotetext{
${ }^{26}$ Peter S. Arno \& Michael H. Davis, Why Don't We Enforce Existing Drug Price Controls? The Unrecognized and Unenforced Reasonable Pricing Requirements Imposed Upon Patents Deriving in Whole or in Part from Federally Funded Research, 75 Tulane L. Rev. 631 (2001).

${ }^{27}$ Peter Arno \& Michael Davis, Paying Twice for the Same Drugs, WASH. POST (Mar. 27, 2002), https://www.washingtonpost.com/archive/opinions/2002/03/27/paying-twice-for-the-same-drugs/c031aa41caaf-450d-a95f-c072f6998931/
} 
such licenses only when the private industry collaborator has not successfully commercialized the invention as a product. ${ }^{28}$

In 2004, Senator Bayh testified at an NIH hearing that was prompted by a march-in petition filed with respect to the AIDS drug Norvir (discussed below). In his testimony, he explained that Congress included the march-in provisions largely to address a fear that "some companies might want to license university technologies to suppress them because they could threaten existing products."

The clear intent of these provisions is to ensure that every effort is made to bring a product to market. If there is evidence of this is not being done, the funding agency can "march-in" and require that other companies be licensed. If the developer cannot satisfy health and safety requirements of the American taxpayer, agencies may march-in. ${ }^{29}$

Sen. Bayh complained that Arno and Davis were trying to "rewrite history," particularly with their assertion that Bayh-Dole provides a mechanism for ensuring that any new drug invented wholly or in part with federal funds will be made available to the public at a reasonable price. He went on to testify that he was surprised to learn that these ill-founded arguments had been formally presented to NIH in the Norvir march-in petition, pointing out that the petition includes purported quotations that "flagrantly misrepresent the legislative history supporting Bayh-Dole," and finding the petition to be plagued by a "complete lack of understanding of how legislative process works." 30 For example, Sen. Bayh pointed out that "[a]ll but one of the citations in the petition used to conclude that march in rights were intended to control prices actually refer to hearings on bills other than Bayh-Dole." The Norvir march-in petition also took statements by Sen. Bayh completely out of context. "The petition language from the Committee report mixes up references to two different sections of the law so that the original meaning is unrecognizable." In his testimony, Sen. Bayh effectively and convincingly explains that the legislative history arguments made in the Arno and Davis article, and adopted by the march-in petitioners, were entirely lacking in merit.

In his testimony, Sen. Bayh went on to point out that NIH had already implicitly determined that price controls are not contemplated by Bayh-Dole when it abandoned its failed "reasonably pricing policy" in 1995, as discussed above. ${ }^{31}$ Attempting to use the Bayh-Dole Act as a mechanism to control drug prices would be expected to cause pharmaceutical companies to avoid the use of patented technology arising under Bayh-Dole, thereby discouraging the commercialization of federally funded technology, and thus defeating the purpose behind BayhDole. Senator Bayh predicted that the likely result of any enforcement of march-in rights against a drug company allegedly charging too much for a drug would be that, in the future, drug

\footnotetext{
${ }^{28}$ Birch Bayh and Robert Dole, Our Law Helps Patients Get New Drugs Sooner, Washington Post 11 Apr. 2002: A28.

${ }^{29}$ NIH Public Meeting on Norvir/Ritonavir March-in Request (May 25, 2004), available at https://www.ott.nih.gov/sites/default/files/documents/2004NorvirMtg/2004NorvirMtg.pdf.

30 Id.at 3.

${ }^{31}$ Citing National Institute of Health, NIH Response to the Conference Report Request for a Plan to Ensure Taxpayers' Interests are Protected (Washington: U.S. Government Printing Office, 2001) 9.
} 
companies will "simply walk away from collaborations with the public sector," as they had done when NIH had tried to implement the 1989 "reasonable pricing" policy.

Sen. Bayh acknowledged that the intent behind the Norvir march-in petition was to expand access to the drug, which is an understandable concern, but he cautioned that:

As you search for a solution to the problem before us today, be aware of unintended consequences tomorrow. Insuring the health of our citizens requires the wisdom and determination for a long journey. The procedures of Bayh-Dole have saved countless lives and pain and suffering. It provides an incentive for further progress in the future. ${ }^{32}$

\section{March-in Petitions prompted by an allegedly over-priced drug}

In the forty years since Bayh-Dole was enacted, the government has apparently never exercised its march-in rights. ${ }^{33}$ But groups have on a number of occasions filed petitions with federal agencies asking them to assert march-in rights, usually in connection with drugs and other technology relating to the life sciences and healthcare. ${ }^{34}$ In 2016, Professor Thomas reported that, as of then, NIH had received six march-in petitions and denied each of them. ${ }^{35}$ In denying the requests, the NIH has repeatedly concluded that the patented technologies were being made reasonably available under the patent, and voiced concern that exercising its march-in rights would act as a disincentive for investment in the development of commercial products based on inventions patented under Bayh-Dole. ${ }^{36}$ It has also stated that the march-in right is not intended to be used to compel patent holders to make patented technology available at lower prices, and that "manufacture, practice, and operation .... [by the patent holder providing for] availability and use by the public" is sufficient to meet the standard. ${ }^{37}$

An early march-in petition that was explicitly based on the allegedly unreasonable price of a drug, in particular ritonavir, was filed in 2004 by an organization called Essential Inventions. Ritonavir is sold under the trade name Norvir by Abbott and is used in the treatment of AIDS. The petition requested that NIH:

exercise Bayh-Dole March-in rights and grant an open license to use six patents related to the manufacture of ritonavir. The grounds for the request are that the patent owner charges unreasonable prices for Norvir/ritonavir, harming the public.

\footnotetext{
32 Id. at 6.

33 John R. Thomas, March-in Rights Under the Bayh-Dole Act, Congressional Research Service Report R44597 (2016) (citing , William O'Brien, "March-In Rights Under the Bayh-Dole Act: The NIH's Paper Tiger?," Seton Hall Law Review, vol. 43 (2013), p. 1403.).

${ }^{34}$ Knowledge Ecology International, Several march-in and royalty free rights cases, under the Bayh-Dole Act, available at https://www.keionline.org/cl/march-in-royalty-free.

35 John R. Thomas, March-in Rights Under the Bayh-Dole Act, Congressional Research Service Report R44597 (2016) (citing , William O'Brien, "March-In Rights Under the Bayh-Dole Act: The NIH's Paper Tiger?," Seton Hall Law Review, vol. 43 (2013), p. 1403.).

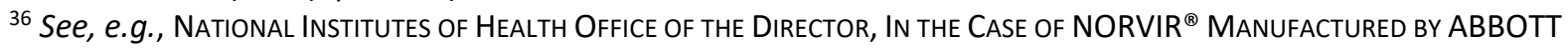
LABORATORIES, INC., available at http://www.essentialinventions.org/docs/usa-ritonavir/zerhouni29jul04.pdf (last visited Feb. 25, 2008).

37 Id. at 5-6.
} 


\section{PRE-PRINT VERSION}

The license should be open to any qualified application, grant the right to make, use, import, export and sell ritonavir, either as a standalone protease inhibitor or as a component of a fixed dose combination treatments. The license should include a five percent royalty to the patent owner, calculated on the basis of the generic sale price for standalone ritonavir products. The open license should also require every manufacture of generic ritonavir to contribute to an R\&D Fund for AIDS. ${ }^{38}$

The petition alleged that march-in was appropriate because the patented drug had not been made available "to the public on reasonable terms," citing the 2001 Arno and Davis article. The NIH held a public hearing with testimony from a number of individuals holding diverse points of view, including the testimony of Senator Bayh discussed above. ${ }^{39}$

In denying the petition, NIH explained that its success in accomplishing the agency's "colossal task" of bringing scientific discoveries emanating from its sponsored research from "the bench to the bedside," including "drug and product development, scale-up, clinical testing, and finally marketing and distribution...requires the participation of industry partners." 40

It is important to the NIH that pharmaceutical companies commercialize new health care products and processes incorporating NIH-funded technology thereby making the technology available to the public. A central purpose of the Bayh-Dole Act involves the development and commercialization of such products out of federally-funded research.

[T] he record in this instance demonstrates that Abbott has met the standard for achieving practical application of the applicable patents by its manufacture, practice, and operation of ritonavir and the drug's availability and use by the public. Ritonavir has been on the market and available to patients with HIV/ADDS since 1996, when it was introduced and sold under the tradename Norvir ${ }^{\circledR}$. Thus, the invention has reached practical application because it is being utilized and has been made widely available for use by patients with HIV/AIDS for at least eight years.

[B]ecause the market dynamics for all products developed pursuant to licensing rights under the Bayh-Dole Act could be altered if prices on such products were directed in any way by NIH, the NIH agrees with the public testimony that suggested that the extraordinary remedy of march-in is not an appropriate means of controlling prices. The issue of drug pricing has global implications and, thus, is appropriately left for Congress to address legislatively. ${ }^{41}$

\footnotetext{
38 Petition to Use Authority under Bayh-Dole Act to Promote Access to Ritonavir (January 29, 2004), available at http://www.essentialinventions.org/legal/norvir/norvir-29jan04petition.pdf.

${ }^{39}$ NIH Public Meeting on Norvir/Ritonavir March-in Request (May 25, 2004), available at https://www.ott.nih.gov/sites/default/files/documents/2004NorvirMtg/2004NorvirMtg.pdf.

${ }^{40} \mathrm{NIH}$ Office of the Director, In the Case of NORVIR ${ }^{\circledR}$ Manufactured by ABBOTT LABORATORIES, INC. (July 29, 2004), available at http://www.essentialinventions.org/docs/usa-ritonavir/zerhouni29jul04.pdf.

${ }^{41} / d$.
} 
On the same day it filed the Norvir petition, Essential Inventions filed another petition asking NIH to assert its march-in rights with respect to patents on latanoprost, sold by Pfizer under the tradename Xalatan for use in the treatment of glaucoma. The petition argued that the drug was not being made available to U.S. patients on "reasonable terms," because the U.S. price is significantly higher than the price charged in Canada and Europe. Essential Inventions proposed a remedy similar to that proposed in the ritonavir/Norvir petition, i.e. NIH would compel licensing pursuant to which generic manufacturers would pay the patent holder a 5\% royalty and make a mandatory contribution to an R\&D fund. No hearing was held in this case, and NIH rejected the petition for reasons similar to its rejection of the Norvir petition, finding that the "record in this instance demonstrates that Pfizer has met the standard for achieving practical application of the applicable patents by its manufacture, practice and operation of latanoprost and the drug's availablity and use by the public." The NIH stated its belief that "the extraordinary remedy of march-in is not an appropriate means of controlling prices," and that "the issue of whether drugs should be sold in the United States for the same price as they are sold in Canada and Europe has global implications and, thus, is appropriately left for Congress to address legislatively." 42

On January 14, 2016, KEI and the Union for Affordable Cancer Treatment (UACT) petitioned NIH, HHS, and the Department of Defense (DoD) requesting that the federal agencies (1) exercise their march-in authorities, or (2) exercise the federal governments nonexclusive royaltyfree government use license for enzalutamide, a drug is used for treating prostate cancer and sold by the Japanese drug company Astellas under the tradename Xtandi. ${ }^{43}$ The petition alleges that the three patents listed in the Orange Book for Xtandi, all of which were assigned to the Regents of the University of California and based on inventions emanating from UCLA, were made with the support of NIH and DoD grants. In their petition, they argue that march-in is justified because the cost of the drug is much higher in the U.S. than in other countries, such that is excessive and discriminatory as regard to U.S. citizens, and thus the patented technology had not been made "available to the public on reasonable terms."

On June 20, 2016, Francis Collins, NIH's Director, sent KEI a letter denying the request. ${ }^{44}$ In the letter, Collins noted that the practical application of the invention was evidenced by the "manufacture, practice, and operation" of the invention and the invention's "availability to and use by the public." Xtandi is broadly available as a prescription drug. As evidence, Collins pointed to sales figures for enzalutamide provided in KEI's petition letter, showing a 77\% increase in sales from 2013 to 2014, and a projected increase of 51\% from 2014 the 2015.

\footnotetext{
${ }^{42} \mathrm{NIH}$ Office of the Director, In the Case of Xalatan ${ }^{\circledR}$ Manufactured by PFIZER, INC. (September 17, 2004), available at https://www.ott.nih.gov/sites/default/files/documents/policy/March-in-xalatan.pdf.

${ }^{43}$ Xtandi March-in request letter (January 14, 2016), available at https://www.keionline.org/wpcontent/uploads/Xtandi-March-in-Request-Letter-14Jan2016-1.pdf.

${ }^{44}$ Letter from Collins denying Xtandi march-in request (June 20, 2016), available at https://www.keionline.org/wpcontent/uploads/Final-Response-Goldman-6.20.2016.pdf.
} 


\title{
2016 letter from Congress to HHS and $\mathrm{NIH}$
}

On January 11, 2016 (days before the KEI's Xtandi march-in petition was filed) 51 members of Congress sent a letter to HHS and NIH urging the agencies to utilize march-in rights "to respond to the soaring cost of pharmaceuticals." ${ }^{\prime 4}$ In particular, they asked NIH to issue guidelines "regarding the situations in which march-in rights would apply," in order to "discourage drug price gouging." The letter states:

\begin{abstract}
We are confident reasonable guidance can be put in place to address price gouging while ensuring that march-in rights are exercised with transparency and fairness. We want pharmaceutical manufacturers to have the certainty of clear guidelines that indicate when march-in rights apply. Because these rights would only be used when wrongdoing occurs, innovation should not be threatened. Establishing strong guidelines protects consumers while reducing the need for having to actually exercise "march-in" rights. With adequate guidance, pharmaceutical companies should be able to make better-informed pricing decisions.
\end{abstract}

. .

[W]e believe that just the announcement of reasonable guidelines in response to price gouging would positively influence pricing across the pharmaceutical industry. The decision how to best use that conduit is appropriately addressed through your prompt action. Just beginning that process will have at least a modest salutary impact on this troubling healthcare problem. ${ }^{46}$

\section{6 letter from NGOs to HHS}

In 2016, a group of non-governmental organizations (NGOs) sent a letter to HHS urging the U.S. government to use its "nonexclusive, nontransferable, irrevocable, paid-up license to practice or have practiced for or on behalf of the United States any subject invention throughout the world" to authorize a Canadian company (Biolyse Pharma) to manufacture a generic version of enzalutamide (Xtandi) for distribution in developing countries. ${ }^{47}$ The letter argued that the patent owner, Astellas, "is charging an excessive price for Xtandi, even though the drug was invented and developed with funding from the NIH and the U.S. Army."

The letter asserts that prostate cancer is the second leading cancer in men worldwide, with rates rising quickly in emerging economies, and that if the U.S. government fails to take this action it will be "part of the problem." "If the U.S. ignores or rejects the request, and no agreement is forthcoming, access to the prostate cancer will be restricted, and unequal."

\section{Senate armed services committee 2017 directive}

The report of the Senate Armed Services Committee on the National Defense Authorization Act of 2018, S. 1519, published July 10, 2017, includes the following directive:

\footnotetext{
${ }^{45}$ Knowledge Ecology International, 2016: 51 members of Congress have asked the NIH to use March-In rights to rein in high drug prices (2016), available at https://www.keionline.org/22983.

${ }^{46} / d$.

${ }^{47}$ Knowledge Ecology International, 56 NGOs ask US Government enable export of low cost generic versions Xtandi to developing countries (2016)(citing 35 U.S.C. § 202(c)(4)), available at https://www.keionline.org/23174.
} 
The committee directs the Department of Defense (DOD) to exercise its rights under sections 209(d)(1) or 203 of title 35, United States Code, to authorize third parties to use inventions that benefited from DOD funding whenever the price of a drug, vaccine, or other medical technology is higher in the United States than the median price charged in the seven largest economies that have a per capita income at least half the per capita income of the United States. ${ }^{48}$

The directive is reportedly intended to address the cost of Xtandi and a Zika virus vaccine, both of which are purportedly covered by patents that arose out of research funded by DoD. ${ }^{49} \mathrm{KEI}$ director James Love commented that "[i]f the amendment becomes law, it will be the first time in more than 25 years that U.S. residents get any type of protection on the pricing of taxpayerfunded drugs or vaccines." 50 However, a spokesperson for PhRMA complained that the proposal "ignores the subsequent substantial R\&D investments and risks undertaken by the private sector in developing and bringing a new medicine to patients. ... This amendment would undermine critical intellectual property rights and incentives, create substantial uncertainty for companies, and establish completely arbitrary criteria for taking intellectual property[.] This could chill critically needed collaborations and investment by the private sector to address some of our most serious unmet medical needs." ${ }^{51}$ The directive has apparently not been acted on.

\section{State attorneys general's Remdesivir march-in petition}

On August 4, 2020, a bipartisan coalition of over 30 state attorneys general, led by California's Xavier Becerra and Louisiana's Jeff Landry, sent a letter to HHS, the NIH, and the FDA requesting that the agencies invoke Bayh-Dole's "march-in" provision to demand that Gilead Sciences license remdesivir to other manufacturers. ${ }^{52}$

In their letter, they allege that the price of remdesivir is too high, which "will impede access to treatment in the U.S. and further strain state budgets," and that by using its march-in rights the government can "ensure that Americans can afford and access a sufficient supply of remdesivir during this pandemic. Alternatively, at a minimum, we ask that you support states by assigning to states the ability to use the march-in rights under this law to achieve the same purposes." They allege that "[r]emdesivir has benefited from millions of dollars of public funding, including a \$30-million NIH-funded clinical trial estimated for this fiscal year alone." They also urged the agencies to "make full and immediate use of your legal authority under the Defense Production Act to put the weight of the federal government behind a rapid scaling up of remdesivir production and distribution."

\footnotetext{
48 115TH Congress, 1st Session, 2017, Senate Report 115-125. National Defense Authorization Act for Fiscal Year 2018. Report to accompany S. 1519, page 173. Available at https://www.congress.gov/115/crpt/srpt125/CRPT115srpt125.pdf .

${ }^{49}$ Eric Sagonowsky, Forget Sanofi's Zika shot. A new measure would limit pricing on all DOD-funded medication, Fierce Pharma (Jul 6, 2017), available at https://www.fiercepharma.com/regulatory/senator-pushes-for-cheaperdod-funded-drugs-and-vaccines.

50 ld.

51 Id.

52 State AG's Remedesivir Letter (August 4, 2020), available at https://www.oag.ca.gov/system/files/attachments/press-docs/Remdesivir\%20Letter\%2020200804.pdf.
} 
An article published by Bloomberg Law points out that "the HHS, intellectual property lawyers, and one of the authors of the Bayh-Dole Act argue the attorneys general fail to grasp the basic provisions of the law: March-in rights are not triggered by high drug prices, and federal funds never actually went toward the development of remdesivir." 53 An HHS spokesperson is quoted as commenting that:

We can only exercise march-in rights where the IP to make the product, as a whole, was funded by the federal government[.] ALL of the patents underlying the product have to have been conceived or reduced to practice with federal funds for Bayh-Dole's march-in provision to be of any practical significance. We do not believe this to be the case here. ${ }^{54}$

A spokeswoman for Gilead said the company was "deeply disappointed" that the AGs chose to "misrepresent facts" regarding access to remdesivir. ${ }^{55}$

\section{KEI's letter to HHS urging assertion of other provisions of Bayh-Dole}

While to date KEI and its allies have focused primarily on Bayh-Dole’s $\$ 203$ march-in provisions and the government's royalty-free rights in patents, in 2020 KEI wrote a letter to HHS urging the use of three other provisions of Bayh-Dole to regulate drug prices, particularly with respect to cures responding to the coronavirus pandemic. In their letter, they argue that the US can use these provisions to assign rights in patents to the World Health Organization or other entities, retain title to contractor patents, and even to leverage U.S. funding to obtain open licensing of contractor patents not funded by the U.S. government. ${ }^{56}$

In particular, the letter urges the following three actions:

The United States should enter into agreements with the World Health Organization and other appropriate entities to enable assignments of patent rights under 35 U.S.C. $\S 202(c)(4)$;

The United States should create the mechanisms to ensure appropriate licensing of non-federally funded contractor patents under 35 U.S.C. § 202(f); and

The United States should restrict or eliminate a contractor's ability to retain title to certain federally funded inventions under the "exceptional circumstances" provision in 35 U.S.C. $\S 202(a)$.

KEI argues that:

Under 35 U.S.C. $\S 202(c)(4)$, in addition to the federal government's royalty-free right, a funding agreement may include "the right to assign or have assigned

\footnotetext{
${ }^{53}$ Valerie Bauman, States Demanding Gilead Drug Seizure Misread Law, Attorneys Say, Bloomberg Law (Aug 6, 2020), available at https://news.bloomberglaw.com/health-law-and-business/states-demanding-gilead-drugseizure-misread-law-attorneys-say.

${ }^{54} / d$. (emphasis in the original)

55 Id.

${ }^{56}$ Knowledge Ecology International, Three areas in Section 202 of the Bayh-Dole Act that require action to ensure sufficient rights in patents on coronavirus relevant inventions (March 14, 2020), available at https://www.keionline.org/32364.
} 
foreign patent rights in the subject invention" to third parties, and other "additional rights ... as are determined by the agency as necessary for meeting the obligations of the United States under any treaty, international agreement, arrangement of cooperation, memorandum of understanding, or similar arrangement.

In the case of the coronavirus, the U.S. should include such a provision in every funding agreement that permits these assignments, pursuant to an agreement with the World Health Organization (WHO). . . . For this to happen, the U.S. government must first enter into one or more agreements, to satisfy the requirements of 35 U.S.C. $\S 202(c)(4)$.

To be as clear as possible, the U.S. may allow the WHO or other UN agencies, governments or even nongovernmental organizations like the Red Cross or Doctors without Border, to use inventions funded by the U.S. government, under conditions or limitations the U.S. determines are in the national interest. But this provision of the Bayh-Dole Act is conditioned on the existence of such an agreement AT THE TIME OF FUNDING.

The letter goes on to assert that under 35 U.S.C. $§$ 202(f):

A funding agreement with a small business firm or nonprofit organization" can "contain a provision allowing a Federal agency to require the licensing to third parties of inventions owned by the contractor that are not subject inventions." Put simply, this means that the U.S. government can leverage its substantial, multibillion dollar funding towards providing competitive access to inventions that the government has not funded, including, but not limited to, existing patent rights.

In other words, KEI is urging the HHS to interpret and apply Bayh-Dole in a manner that extends beyond march-in rights, which are limited to patents that arise out of the federally-funded activity, to encompass "patents owned by the contractor that are not subject inventions." The letter does acknowledge that " $\mathrm{t}]$ his is a narrow authority, and requires 'the head of the agency" to determine that 'the use of the invention by others is necessary for the practice of a subject invention or for the use of a work object of the funding agreement and that such action is necessary to achieve the practical application of the subject invention or work object."'

Finally, KEI argues that "[u]nder 35 U.S.C. $§ 202(a)$, the federal government may limit or eliminate a contractor's ability to retain title to a federally funded invention, "in exceptional circumstances, when it is determined by the agency that restriction or elimination of the right to retain title to any subject invention will better promote the policy and objectives of this chapter[.]" KEI asserts that the coronavirus pandemic is the sort of "exceptional circumstance" that would permit the federal government to invoke 35 U.S.C. $\S 202$ (a) in order to retain title to inventions by contractors relating to the coronavirus pandemic, and to manage such rights in the public interest directly, rather than depending upon the normal, more modest safeguards for contractor inventions, such as the more problematic provisions for federal march-in rights set out in 35 U.S.C. $\S 203 . "$ 


\section{HHS v Gilead: The government sues a collaborator}

A lawsuit recently filed by the U.S. government against Gilead illustrates another potential risk drug companies face when they decide to involve themselves with a governmental agency - the agency might patent a discovery that comes out of a collaborative research venture and turn around and sue the drug company for patent infringement. ${ }^{57}$ This is a surprising development. Companies like Gilead might not have foreseen that collaboration with a government agency could come back to haunt them in this way. But Gilead's experience, as the forth in this section the Article, could cause drug companies to reconsider entering into such arrangements in the future.

\section{The CDC-Gilead collaboration}

Gilead has long been involved in efforts to identify and develop treatments for HIV, and has brought more than a dozen products to market for the treatment and prevention of HIV, including Truvada and Descovy. As explained in an earlier Holman Report, Truvada and Descovy are fixed-dose combinations of two antiretroviral agents, a tenofovir prodrug and emtricitabine (FTC). ${ }^{58}$ The prodrug in Truvada is tenofovir disoproxil fumarate (TDF), while in Descovy the prodrug is tenofovir alafenamide fumarate (TAF). Truvada obtained FDA marketing approval for Truvada and Descovy for use in the treatment of HIV in 2004 and 2016, respectively. TDF and TAF both release tenofovir, the actual active ingredient, subsequent to ingestion. However, TAF is effective at lower dosages than TDF, and is believed to be less prone to causing adverse side effects, particularly damage to kidneys, bones, and teeth, that have been associated with use of TDF in some patients. ${ }^{59}$

Over the years Gilead has collaborated with the CDC in various research studies relating to the use of antiretroviral agents for the prevention of HIV-1. Of particular significance to the present patent dispute, beginning in 2004 CDC researchers approached Gilead for assistance in designing studies relating to HIV prophylaxis, using the rhesus macaque (a type of Old World monkey) as the model. ${ }^{60}$ Gilead and CDC entered into a collaborative relationship pursuant to which Gilead provided CDC with free pharmaceuticals and active compounds for use in experiments. In connection with these studies, CDC and Gilead entered into four separate Material Transfer Agreements ("MTAs") between 2004 and 2014 wherein Gilead agreed to provide tenofovir, TDF, and/or FTC to CDC at no cost, for use in HIV-1 research, and the CDC agreed to certain conditions, including to "promptly notify" Gilead of any claimed "Inventions" arising out of the MTAs.

\footnotetext{
${ }^{57}$ Complaint, The United States of America v. Gilead Sciences, Inc. and Gilead Sciences Ireland UC, 1:19-cv-02103UNA (Delaware Dist. Ct., November 6, 2019)(the "HHS complaint").

${ }^{58}$ Christopher M. Holman, Gilead Sciences Sued for Failing to Bring a Follow-On Version of Truvada to Market Sooner, 38 BIOTECHNOLOGY LAW REPORT 267 (2019). Emtricitabine is commonly referred to as FTC, based on its systematic name (2',3'-dideoxy-5-fluoro-3'-thiacytidine).

${ }^{59}$ Id.

${ }^{60}$ Complaint, Gilead Sciences, Inc. v. The United States of America, 1:20-cv-00499-CFL (Court of Federal Claims, April 24, 2020)(the "Gilead complaint"). The facts in this section of the Article are largely gleaned from this complaint, filed by Gilead against the government in response to the government's infringement suit, and the HHS complaint cited previously.
} 
Gilead and the CDC also entered into a Clinical Trial Agreement ("CTA") in 2004, pursuant to which Gilead would provide antiviral products free of charge for a clinical trial about HIV prevention in Botswana. In particular, Gilead agreed to provide 37,080 bottles of Truvada and matching placebos, the value of which Gilead estimates to be in excess of $\$ 6.7$ million, which Gilead delivered in a timely manner. The CDC agreed, among other things, "to put the results of the Trial, patentable or otherwise, in the public domain for all to use without obligation or compensation to CDC." CDC further agreed "not to seek patent protection in connection with any inventions that derive from the use of the Study Drug in the Trial."

\section{The CDC patents Truvada for PrEP}

In 2006, CDC filed a provisional patent application describing the results of a study in which a group of six rhesus macaques were injected once daily with tenofovir and FTC, and then subjected to weekly rectal exposure to a low dose of simian-HIV (SHIV). The study found that the combination of tenofovir and FTC provided a high level of protection against repeated virus challenges. Gilead claims that this study arose out of the MTAs, and employed tenofovir and FTC supplied by Gilead.

In 2007 CDC filed a non-provisional application claiming priority to the provisional application. This non-provisional application does not disclose the study described in the provisional application, but does disclose a study in which rhesus macaques were divided into three study groups of six macaques each and treated with three different daily prophylaxis regimens, involving either subcutaneous or oral administration of FTC, TDF, and/or tenofovir. According to the application, the three studies concluded that each of the three prophylaxis regimens was "protective to a degree with a clear dose-response relationship being observed." Again, Gilead claims that these studies fell within the scope of the MTAs, and employed drugs that Gilead freely provided to CDC under the MTAs.

Four patents have issued to the government claiming priority to these applications and naming as inventors CDC investigators specifically identified in the MTAs (the "HHS Patents"). The patents are generally directed to the use of tenofovir/FTC or Truvada for HIV-1 pre-exposure prophylaxis ("PrEP"). The nature of the patented inventions is illustrated by Claim 1 of the first of the patents to issue, U.S. Patent No. 9,044,509 (the '509 patent), which issued on June 2, 2015 which recites:

1. A process of protecting a primate host from a self-replicating infection by an immunodeficiency retrovirus comprising:

(a) selecting a primate host not infected with the immunodeficiency retrovirus, and

(b) administering directly to an uninfected primate host a combination comprising:

i. a pharmaceutically effective amount of emtricitabine [FTC]; and 
ii. a pharmaceutically effective amount of tenofovir or tenofovir disoproxil fumarate,

wherein the combination is administered prior to an exposure of the primate host to the immunodeficiency retrovirus, thereby protecting the primate host from infection with the immunodeficiency retrovirus, wherein the combination is administered orally.

Gilead alleges the that while the patent applications were pending, the government (acting through FDA) encouraged Gilead to seek FDA approval to market Truvada for HIV-1 PrEP, and that Gilead did receive that approval on July 16, 2012. However, Gilead alleges that the government failed to provide notice of the pending patent applications covering Truvada for PrEP, as it was required to do under the agreements. This is significant, because it is this FDA approval of use of Truvada for PrEP (as opposed to use of Truvada for the treatment of people who have AIDS, which was the originally approved indication) that serves as the basis for the infringement lawsuit.

Gilead argues that if it had been aware of the pending applications, it might have taken different actions with respect to seeking approval for Truvada for PrEP. For example, Gilead could have chosen not to seek FDA approval for PrEP use of Truvada, at least absent assurance that the government would not turn around and sue it for patent infringement based on the approval. If Gilead had not secured FDA approval, PrEP use would not appear on the label, and Gilead could not market the drug for that use, but the drug could still be used off-label for PrEP, and under that scenario it would appear that Gilead would not be liable for infringing the government's patents. ${ }^{61}$

The government, on the other hand, alleges that it did inform Gilead of the pending patent applications. For example, in 2008, CDC researchers published an article, entitled Prevention of Rectal SHIV Transmission in Macaques by Daily or Intermittent Prophylaxis with Emtricitabine and Tenofovir, that discloses the macaque prophylaxis studies. The government points out that, shortly before publication, CDC provided a draft copy to Gilead for its review. The draft included a sentence stating that five of the authors were "named in a U.S. Government patent application related to methods for HIV prophylaxis." There was no specific reference to the applications that were filed, and Gilead argues that the sentence did not provide reasonable notice of the filing of the provisional and non-provisional patent applications. The government counters, however, that this statement, which also appeared in other CDC-authored publications between 2010 and 2016, satisfied its contractual obligation to "promptly notify" Gilead of any claimed "Inventions" arising out of the MTAs and CTA.

Gilead disputes this, however, and argues that the first actual notice it received of the pending patent applications came in 2014, when CDC sent emails to Gilead informing the company that CDC had developed technology for using Truvada in PrEP, and that Gilead "appears to be an

\footnotetext{
${ }^{61}$ See generally, Christopher M. Holman, GlaxoSmithKline v. Teva: Holding a Generic Liable for an Artificial Act of Inducement, 39 BIOTECHNOLOGY LAW REPORT 425 (2020).
} 
ideal partner" for the technology. The emails also stated that CDC was pursuing U.S. and foreign patent applications for the technology. In 2016, CDC followed up on its 2014 invitation to "partner" with an email informing Gilead of the HHS patents and stating that CDC "believe[s] that your marketed drug, Truvada, may be covered by these patents," that the patented inventions are available for licensing on a nonexclusive basis, and that CDC "would be happy to discuss an amicable resolution to this matter." Gilead complains that between the 2006 filing of the provisional application and the 2014 emails Gilead and CDC were engaged in numerous research collaborations, and CDC never informed Gilead of the applications or patents.

\section{Controversy over the price of Truvada}

AIDS activists and some in the medical community have criticized Gilead's pricing of Truvada in the United States, and have pressured to the government to intervene. ${ }^{62}$ In particular, they argue that the government funded much of the clinical research on the use of Truvada for PrEP, and that taxpayers are essentially "paying twice" for the results of that research. Activists became aware of the HHS Patents and see them as a way to leverage lower pricing of and expanded access to Truvada for PrEP,. In particular, they have argued that by enforcing its patents, the government could effectively force Gilead to agree to lower the price it charges for its drugs. They also assert that the government should be obtaining royalties from Gilead for the company's substantial sales of Truvada for PrEP, and should use those royalties to expand access of PrEP, by using it to pay for the drug for those who cannot afford it.

In May, 2019, a House Oversight Committee convened a hearing to address these concerns. ${ }^{63}$ During the hearing, Gilead's CEO Daniel O'Day testified that the company believes that the HHS Patents are invalid because " $[\mathrm{u}]$ sing Truvada for PrEP was well known in the scientific community, long before CDC claimed it as an invention." ${ }^{4}$ However, he further stated that Gilead had "chosen not to challenge those patents because we value our collaborative relationship with the agency."

\section{The government sues Gilead}

Perhaps bowing to pressure from the public and Congress, on November 6, 2019, the government filed suit against Gilead alleging infringement of the patents, based on Gilead's sale and promotion of Truvada and Descovy products for PrEP. The Government seeks royalties on Gilead's past sales of Truvada and Descovy for use in PrEP, as well as an ongoing royalty for future sales of both products, which Gilead asserts would amount to millions of dollars.

Gilead has raised several defenses, including that the HHS Patents are invalid and/or unenforceable. Among other things, Gilead alleges that certain prior art would anticipate and/or

\footnotetext{
62 See, e.g., \#BreakThePatent, https://breakthepatent.org [https://perma.cc/8FT5-Q7UV] ("The drug costs less than $\$ 6$ a month to make but Gilead charges patients more than $\$ 1,600$ for a 30 day supply."); id. ("The manufacturer of the Truvada, Gilead Sciences, has inflated the price by more than 25,000\% ... [w] hat Gilead charges for just two pills could pay for an entire year's supply of a generic equivalent.").

${ }^{63}$ HIV Prevention Drug: Billions in Corporate Profits After Millions in Taxpayer Investments: Hearing Before the H. Comm. on Oversight and Reform, 116th Cong. 5 (2019).

${ }^{64}$ C-SPAN, Price of HIV Prevention Drug Truvada (May 16, 2019), available at https://www.cspan.org/video/?460810-1/gilead-ceo-daniel-oday-testifies-truvada-hiv-prevention-drug-pricing.
} 
render obvious certain claims of the HHS patents. On December 2, 2019, shortly after it filed its infringement lawsuit, the Government disclaimed some of its patent claims, and Gilead asserts that the government did so because it recognizes that it failed to disclose material prior art during prosecution the patents. ${ }^{65}$

In its complaint, the government asserts that hundreds of millions of taxpayer dollars funded clinical studies that confirmed that the patented PrEP regimens are 99\% effective in preventing new HIV infections, and that Gilead has reaped billions of dollars from PrEP through the sales of Truvada and Descovy. The government further argues that Gilead has exaggerated its role in developing PrEP, ignoring CDCs clear contributions, and baselessly denying the validity of the patents. The government acknowledges that Gilead contributed to the CDC's patented research by providing samples of the drug that the CDC used for testing purposes, but argues that that was the only contribution. The Gilead complaint asserts that the HHS complaint acknowledges that the patents arose out of research conducted pursuant to at least one of the MTAs.

The Government goes on to assert that the patented inventions were made possible through new and precise animal modeling methods developed by CDC researchers that proved superior in simulating human HIV infections than previous animal models. In particular, in prior animal research on HIV treatment and transmission, SIV or SHIV was introduced into macaque (or other primate) models in a single high dose at a mucosal surface such that most, if not all, of the macaques would acquire an infection that could cause a disease similar to AIDS. According to the government, this methodology did not actually represent the type of repeat, low-dose mucosal exposure experienced by humans with a sexual transmission of HIV, and thereby could underestimate efficacy. CDC developed new methodology whereby the virus was administered into rhesus macaques in repeated and precise low doses, either vaginally or rectally. They also used a SHIV that more closely resembled HIV-1, and thus better simulated human HIV transmission. It was innovations such as these, along with the determination of proper dosing for the experiments, that, according to the government, resulted in the patented inventions.

In its complaint, the government emphasizes that Gilead's only contribution to the inventions was the donation of the pharmaceutical compounds. The government points out that the MTAs specify that the government would "retain title to any patent or other intellectual property rights in inventions made by its employees in the course of the Research Project," and that Gilead had agreed in the MTAs to use any research results from CDC "solely for internal research purposes."

The government further alleges that Gilead was initially reluctant to promote and support PrEP commercially. However, in 2014 favorable clinical data coming out of studies funded primarily by the NIH and the Bill and Melinda Gates Foundation caused CDC to issue comprehensive clinical guidelines recommending that daily PrEP be considered for HIV prevention in all people who are at a substantial risk. The World Health Organization (WHO) issued a similar recommendation in 2015 after studies showed that PrEP was highly effective at reducing risk of HIV infection among high-risk populations in real-world settings. The government asserts that,

\footnotetext{
${ }^{65}$ Gilead complaint.
} 
following these new guidelines, sales for Truvada for PrEP skyrocketed in the United States and abroad, and that in response to the increased demand Gilead has significantly increase the price it charges for the drug. The government asserts that Truvada for PrEP is a critical component of its efforts to end the HIV epidemic, but that the drug's high cost presents a critical barrier to increasing access to PrEP in the United States.

According to the government, some drug companies that are marketing generic versions of Truvada in other countries (where there are no Gilead patents currently preventing it) have entered into a licensing arrangement with the government with respect to HHS's non-U.S. PrEP patents. For exmple, Mylan has acquired a multi-country license to the patents, and is currently paying a royalty to sell generic Truvada products in Australia, Canada, Germany, France, and United Kingdom. Prior to taking the license, Mylan challenged a European counterpart to the HHS Patents through opposition proceedings at the European Patent Office, where the validity of the patent was ultimately upheld. The government reports that it is currently negotiating licensing arrangements with other companies seeking to sell generic versions of Truvada in Europe, Canada, and Australia.

According to the government's complaint, as of that time it was filed (in 2019) multiple companies had filed ANDA applications to sell generic versions of Truvada in the United States, and at least three had been approved: Teva, Mylan, and Aurobindo Pharma Ltd. Of these, only Mylan had licensed the HHS Patents as of that time, but the government reported that it was actively attempting to negotiate licenses with other companies intending to market generic Truvada in the United States. Teva entered the market with its generic version of Truvada in October 2020, making it the first generic version of the drug to be available in the U.S.

In its complaint, the government alleges that Gilead has engaged in multiple acts of willful infringement of the HHS patents. Some of the allegations describe direct infringement, and in particular the assertion that Gilead "has conducted and continues to conduct closely controlled clinical trials, including those needed to obtain FDA approval of Descovy for PrEP." The other allegations are based on theories of induced patent infringement under 35 USC $\S 271$ (b). In particular, the complaint alleges that since 2012, when FDA first approved the use of Truvada for PrEP, Gilead has marketed and sold the drug for that purpose. The complaint alleges that since the first of the HHS patents issued in 2015, Gilead has received approximately $\$ 6.7$ billion in revenue from the sales of Truvada in United States, and that while the percentage of sales attributable to use of the drug for PrEP has fluctuated over time, Gilead reported in the first quarter 2019 the more than $60 \%$ of those taking Truvada were taking it for PrEP.

According to the government, Gilead has repeatedly instructed healthcare providers and patients on administration of a Truvada for PrEP regimen. Much of the basis for the allegation of inducement to infringe is based on the FDA-mandated labeling of Truvada, which includes statements that Truvada is indicated along "with safer sex practices for [PrEP] to reduce risk of sexually acquired HIV-1 in adults at high risk." Other acts of alleged inducement include Gilead's publication of a pamphlet entitled "Truvada for a Pre-Exposure Prophylaxis (PrEP) Indication," used to train healthcare providers in the selection and treatment of patients. Gilead also instructs prescribing healthcare providers and their patients to sign a standard "Agreement 
Form" before initiating Truvada for PrEP, wherein the prescriber affirms that the HIV-negative status of the patient has been confirmed and that the prescriber has reviewed the Truvada for PrEP Medication Guide with the patient and will continue to monitor the patient appropriately. The patient acknowledges being HIV negative, agrees to repeat HIV testing every three months, and acknowledges having read the Medication Guide.

The government further asserts that Gilead's trademark registration activities evidence an intent that Truvada be administered as a PrEP regimen, including its registration of a trademark for Truvada for PrEP®, and it application to register "Step Up. PrEP Up." for use in promoting public awareness and providing medical information about the prevention of HIV and AIDS. Gilead has also obtained a U.S. trademark registration for a "three-dimensional configuration of an oblong tablet, combined with the color blue as applied to the entire surface of the tablet" for "PrEP preparations for prevention and risk mitigation of contracting HIV."

In August 2019, Gilead challenged the validity of the four HHS Patents by petitioning for inter partes review (IPR) at the PTO. ${ }^{66}$ However, in February 2020 the PTO denied the petitions with respect to all four of the patents, finding that Gilead had not demonstrated a reasonable likelihood that it would prevail with respect to any of the challenged patent claims. ${ }^{67}$

On April 24, 2020 Gilead sued the U.S. government in the Court of Federal Claims in an action alleging that the CDC has violated the terms of the four MTAs and the CTA. ${ }^{68}$ Gilead alleges that prior to the Government notifying it of the HHS Patents and the assertion that a license is required, Gilead had already invested substantial amounts in educating at-risk patient populations about the potential benefits of Truvada for PrEP. In its complaint, Gilead alleges that if the CDC had promptly provided notice of its filing of the patent applications, as required by the MTAs, that would have allowed Gilead the opportunity to consider taking action, such as providing CDC and/or the PTO with information showing why the patent claims would be invalid, or by changing its application for FDA approval to market Truvada for PrEP. Gilead also argues that the patents never would have issued if CDC had fulfilled its contractual obligations under the CTA to not seek patent protection on alleged inventions derived from the Botswana trial. According to Gilead, the government's own complaint filed in the patent infringement case asserts that the effectiveness of the patented inventions was demonstrated by the results of the Botswana trial.

\section{Conclusion}

The lesson for innovative pharmaceutical companies is clear - government involvement in the development and clinical testing of patented drugs can come at a cost, providing ammunition for

\footnotetext{
66 The PTO proceedings are: IPR2019-01453, IPR2019-0454, IPR2019-01455, IPR2019-01456.

67 Tiffany Hu, PTAB Won't Review 2 More HHS HIV-Prevention Patents, Law360 (February 24, 2020), available at https://www.law360.com/articles/1246150?scroll=1\&related=1; Eric Sagonowsky, Gilead loses again in PrEP patent fight with HHS, sending dispute to federal court, Fierce Pharma (Feb 21, 2020), available at https://www.fiercepharma.com/pharma/gilead-loses-another-prep-patent-challenge-against-hhs-sending-disputeto-federal-court.

${ }^{68}$ Complaint, Gilead Sciences, Inc. v. The United States of America, 1:20-cv-00499-CFL (Court of Federal Claims, April 24, 2020)(the "Gilead complaint").
} 
those who equate government involvement with the taxpayer "paying twice" for the innovator drug. Unfortunately, the more essential a drug is, the more likely it is to be targeted. The ultimate result could be a disincentive for drug companies to develop drugs arising out of federally funded research, or to collaborate with federal agencies in studying or testing their drugs.

Gilead is apparently still cooperating with the federal government in the fight against AIDS, even as they battle over patents in the courts. For example, they are partners in a free drug program for PrEP that distributes HIV prevention drugs to uninsured patients around the country. ${ }^{69}$

Recently, it was reported that Pfizer's efforts to bring its COVID-19 vaccines to market might have been hampered by its refusal to accept any federal money in the development of the vaccine. $^{70}$ If that is the case, it would certainly be a rational decision on Pfizer's part, but it also illustrates how penalizing drug companies for collaborating with the government on drugs can hurt the public interest. Unlike Pfizer, Moderna did except substantial federal funding in connection with the approval of its COVID-19 vaccine, and as would be expected, this has resulted in Moderna becoming a prime target for being scrutinized by KEI and others. ${ }^{71}$

The election of Joe Biden could portend an escalation of the movement to regulate the price of innovative drugs under the guise of preventing taxpayers from "paying twice." Overall, the Trump administration has been seen as relatively friendly to IP rights, although it has been critical of the perceived high cost of drugs in the U.S. compared to other nations, and recently the administration finalized a "most favored nations" rule that "will lower Medicare Part B payments for certain drugs to the lowest price for similar countries." "72 But things could get even tougher for pharma under a Biden administration. For example, President-elect Biden has announced Xavier Becerra as his choice for Secretary of Health and Human Services. ${ }^{73}$ As described above, Becerra recently headed up the petition asking HHS to march-in on Gilead's remdesivir patent rights, even though it appears that the government was not involved in the patents in a way that would render them subject to the provisions of Bayh-Dole. Becerra's petition does, however,

\footnotetext{
${ }^{69}$ Eric Sagonowsky, Gilead loses again in PrEP patent fight with HHS, sending dispute to federal court, Fierce Pharma (Feb 21, 2020), available at https://www.fiercepharma.com/pharma/gilead-loses-another-prep-patentchallenge-against-hhs-sending-dispute-to-federal-court.

${ }^{70}$ Arlene Weintraub, Feds rebuff Pfizer's pleas to speed up supplies of COVID vaccine raw materials: reports, Fierce Pharma (Dec 16, 2020), available at https://www.fiercepharma.com/pharma/feds-rebuff-pfizer-s-requests-forspeedier-supplies-covid-vaccine-raw-materials-reports.

${ }^{71}$ Knowledge Ecology International, Moderna, available at https://www.keionline.org/moderna (providing links to various KEI Reports and Posts describing the group's examination of “issues and contracts related to Moderna's COVID-19 vaccine efforts.").

72 U.S. Department of Health \& Human Services, Trump Administration Announces Prescription Drug Payment Model to Put American Patients First (Nov. 20, 2020), available at https://www.hhs.gov/about/news/2020/11/20/trump-administration-announces-prescription-drug-paymentmodel-to-put-american-patients-first.html.

${ }^{73}$ Ricardo Alonso-Zaldivar, Hichael Balsamo and Jonathan Lemire, Biden picks Xavier Becerra to lead HHS, coronavirus response, AP News (December 7, 2020), available at https://apnews.com/article/joe-biden-pandemicscoronavirus-pandemic-xavier-becerra-harvard-bc89947ff5ad8d21bc272743607d01fa.
} 
suggest that as the head of HHS he might be more receptive to future march-in petitions than has been the case in the past, and perhaps we will see, for the first time, the government invoke its march-in to regulate the price a patented drug. 